\title{
Corrosion Resistance of Mild Steel in Simulated Concrete Pore Solution
}

\author{
M. PANDIARAJAN ${ }^{* a}$, P. PRABHAKAR ${ }^{\mathrm{b}}$ and S. RAJENDRAN ${ }^{\mathrm{c}}$ \\ ${ }^{a}$ Corrosion Research Centre, PG and research Department of Chemistry, \\ G.T.N Arts College, Dindigul- 624 005, India \\ ${ }^{\mathrm{b}} \mathrm{PG}$ and research Department of Chemistry, APA College of Arts and Culture, \\ Palani, Dindigul, India \\ ${ }^{\mathrm{c}}$ Corrosion Research Centre, R.V.S. School of Engineering and Technology, \\ Dindigul- 624 005, India \\ pandiarajan777@gmail.com
}

Received 22 September 2012 / Accepted 20 October 2012

\begin{abstract}
Concrete admixtures can be prepared in various water samples such as rainwater, well water, and seawater. These waters contain various types of ions. So corrosion behavior of mild steel immersed in simulated concrete pore solution prepared with the above water samples will vary. Corrosion resistance of mild steel in simulated concrete pore solution prepared with above water samples has been evaluated by AC impedance spectra. The corrosion resistance of mild steel in various samples of water is as follows: Rainwater $>$ Well water $>$ Seawater. The corrosion resistance of mild steel in simulated concrete pore solution prepared in various water samples are in the decreasing order: Rainwater $>$ Well water > Seawater. This is revealed by charge transfer resistance values and double layer capacitance values.
\end{abstract}

Keywords: Simulated concrete pore solution, Mild steel, Rainwater, Well water, Seawater, AC impedance spectra

\section{Introduction}

Reinforced concrete is widely used for building materials and plays a significant role in economic development. However, the premature degradation of reinforced concrete structures due to the reinforcing steel corrosion has become a serious problem in modern society, which results in a huge economic loss ${ }^{1-3}$.

Under normal conditions, reinforcing steel in concrete can be protected from corrosion by forming a compact passive film on its surface in concrete pore solution with high alkalinity ( $\mathrm{pH}$ 12.5-13.5). However, the passive film can be locally damaged and the localized corrosion of reinforcing steel takes place when $\mathrm{pH}$ and/or the chloride concentration at the steel/concrete interface reach the critical values for corrosion ${ }^{4-9}$. The $\mathrm{pH}$ of concrete pore solution decreased during concrete carbonation due to the neutralization of $\mathrm{Ca}(\mathrm{OH})_{2}$ in the 
interstitial solution with the acidic gases $\left(\mathrm{CO}_{2}, \mathrm{SO}_{2}\right.$, etc. $)$ which diffuse into the steel/concrete interface from the air $^{8}$. The $\mathrm{pH}$ value of concrete pore solution is one of the most important parameters affecting the corrosion behaviour of reinforcing steel in concrete.

In spite of the extensive studies of corrosion behaviours of reinforcing steel ${ }^{4-10}$, the exact mechanism of its depassivation is still unclear. Even though the effect of $\mathrm{pH}$ on the corrosion of reinforcing steel was discovered decades ago, there were only a few studies focusing on the depassivation of the steel caused by decreasing $\mathrm{pH}$ of concrete pore solution during the carbonation process ${ }^{8,11-13}$. In the urban and industrial areas, the acidic gases $\left(\mathrm{CO}_{2}, \mathrm{SO}_{2}, \mathrm{NO}_{2}\right.$, etc. $)$ can make the local atmosphere acidic and attack the hydrated concrete. The reactions of neutralization in concrete may decrease the $\mathrm{pH}$ value of concrete pore solution, induce the steel surface depassivation and consequently cause the steel corrosion.

Several research papers have investigated the corrosion behaviour of metals in presence of simulated concrete pore (SCP) solutions ${ }^{14-25}$. Usually steel rebars have been used in such studies. The Present Study is undertaken to investigate the corrosion of mild steel in SCPS prepared in rainwater, well water and seawater. A saturated solution of calcium hydroxide is used as SCP solution ${ }^{26-30}$. AC impedance spectra has been used to evaluate the corrosion resistance of mild steel.

\section{Experimental}

The composition of mild steel specimen was used in the present study was (wt \%): $0.026 \mathrm{~S}, 0.06 \mathrm{P}, 0.4 \mathrm{Mn}, 0.1 \mathrm{C}$ and balance iron $^{31}$. The composition of rainwater (collected from roof top and stored in concrete tank), well water and seawater used in the present study is given the Table 1.

Table 1. Composition of samples used in the present study

\begin{tabular}{cccc}
\hline Parameters & Rainwater & Well water & Seawater \\
\hline $\mathrm{pH}$ & 8.15 & 8.38 & 7.18 \\
Total Dissolved Solids, ppm & 273 & 2013 & 39392 \\
Electrical Conductivity, micromhos/cm & 390 & 3110 & 57929 \\
Nitrate, ppm & 9 & 0 & 0 \\
Chloride, ppm & 72 & 665 & 16850 \\
Sulphate, ppm & 14 & 14 & 6010 \\
Fluoride, $\mathrm{ppm}_{3}, \mathrm{ppm}$ & 0.2 & 0 & 0 \\
Total Hardness as CaCO & 88 & 1100 & 112 \\
\hline
\end{tabular}

Simulated concrete pore (SCP) solution

A saturated calcium hydroxide solution is used in the present study, as SCP solution. The electrode made of mild steel wire was immersed in the SCP solution and AC impedance spectra were recorded.

\section{AC impedance spectra}

AC impedance spectral studies were carried out in a CHI - Electrochemical workstation with impedance, Model 660A. A three-electrode cell assembly was used. The working electrode was one of the three metals. A saturated calomel electrode (SCE) was the reference electrode and platinum was the counter electrode. The real part (Z') and imaginary 
part (Z”) of the cell impedance were measured in ohms at various frequencies. Values of the charge transfer resistance $\left(\mathrm{R}_{\mathrm{t}}\right)$ and the double layer capacitance $\left(\mathrm{C}_{\mathrm{dl}}\right)$ were calculated.

\section{Results and Discussion}

Corrosion behaviour of mild steel in simulated concrete pore solution (SCP), (saturated calcium hydroxide solution) has been investigated by AC impedance spectra.

Analysis of AC impedance spectra

The AC impedance spectra of mild steel immersed in simulated concrete pore solution prepared in rainwater, well water and seawater are shown in Figures 1 to 11. The Nyquist plots are shown in Figure 1,4,5,6 and 10 and 11. Charge transfer resistance $\left(\mathrm{R}_{\mathrm{t}}\right)$ and double layer capacitance $\left(\mathrm{C}_{\mathrm{dl}}\right)$ values are derived from Nyquist plots. Impedance values, log (z/ohm) and phase angle values are derived from Bode plots. The results are summarized in Table 2.

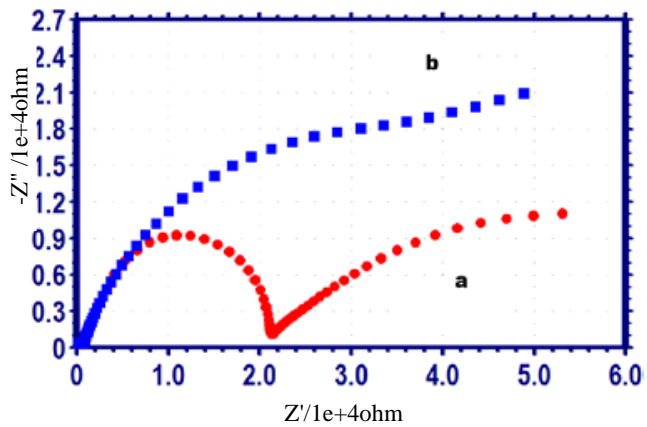

Figure 1. AC Impedance spectrum of mild steel immersed in various test solution (Nyquist plot); a) Rainwater, b) SCPS prepared in rainwater

Table 2. Impedance parameters of mild steel immersed in simulated concrete pore solution (saturated calcium hydroxide solution), obtained by AC impedance spectra study

\begin{tabular}{cccc}
\hline System & $\mathrm{R}_{\mathrm{t}} \mathrm{ohmcm}^{2}$ & $\mathrm{C}_{\mathrm{dl}} \mathrm{F} / \mathrm{cm}^{2}$ & Impedance, log z/ohm \\
\hline Rainwater & 49068 & $1.039 \times 10^{-6}$ & 4.7 \\
SCPS prepared in rainwater & 51228 & $9.95 \times 10^{-7}$ & 4.8 \\
Well water & 825 & $6.18 \times 10^{-5}$ & 3.37 \\
SCPS prepared in well water & 38460 & $1.32 \times 10^{-5}$ & 4.6 \\
Seawater & 83.06 & $6.14 \times 10^{-4}$ & 2.10 \\
SCPS prepared in sea water & 80.48 & $6.33 \times 10^{-4}$ & 2.09
\end{tabular}

When corrosion rate decreases due to the formation of protective film the charge transfer resistance value increases and double layer capacitance value decreases. The impedance value $(\log \mathrm{z} / \mathrm{ohm})$ and -phase angle value increases. It is observed from Table 2, that when mild steel was immersed in rainwater, the $R_{t}$ value was $49068 \mathrm{ohmcm}^{2}$ and the $\mathrm{C}_{\mathrm{dl}}$ value was $1.039 \times 10 \mathrm{~F} / \mathrm{cm}^{2}$. When mild steel immersed in simulated concrete pore solution prepared in rainwater, the $R_{t}$ value increases $\left[51228 \mathrm{ohm} / \mathrm{cm}^{2}\right]$ and $C_{d l}$ value decreases $\left[9.95 \times 10^{-7} \mathrm{~F} / \mathrm{cm}^{2}\right]^{32-41}$. This indicates that a stable protective film is formed on the metal surface in presence of SCPS. This is further supported by the fact the impedance value ( $\log \mathrm{z} / \mathrm{ohm}$ ) increases from 4.7 to 4.8 (Figures 2 and 3). The phase angle value increases from 54 to 56 degree (Figures 2 and 3). In the presence of concrete solution a single time (one time) constant is observed (Figure 3). 

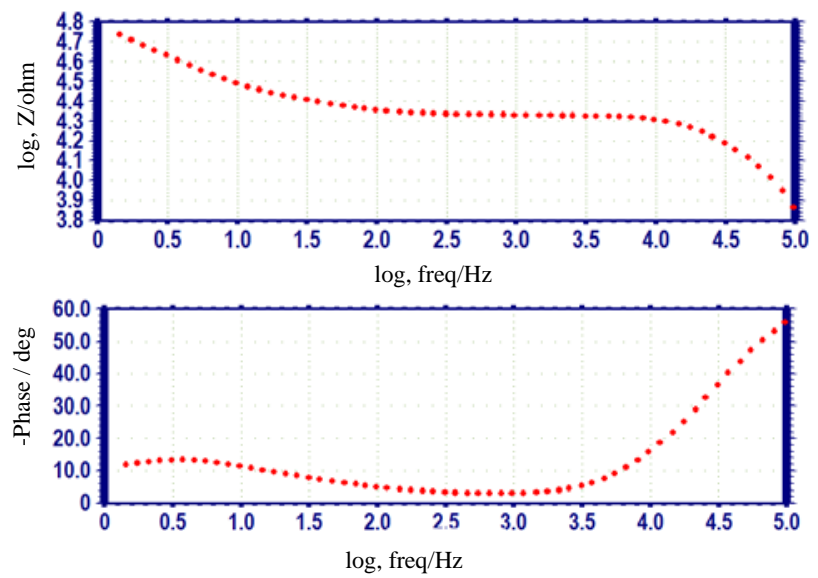

Figure 2. AC Impedance spectrum of mild steel immersed in rainwater (Bode Plot)
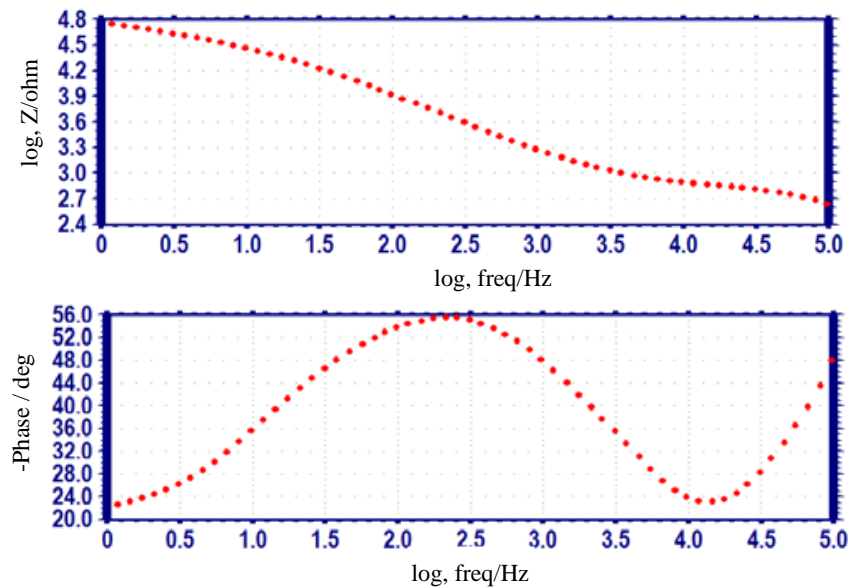

Figure 3. AC Impedance spectrum of mild steel immersed in SCPS prepared in rainwater (Bode plot)

It is observed from Figure 1 that when mild steel was immersed in rainwater two semi circles were observed. This is characteristic of a protective film formed and then broken. The breaking of the film is due to the presence of corrosive ions such as chloride, sulphate and fluoride present in rainwater (Table 1). The equivalent circuit diagram for such system is shown in Scheme 1.

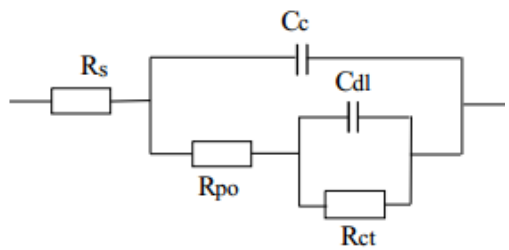

Equivalent circuit for a failed coating

$\mathrm{C}_{\mathrm{c}}$ - The capacitance of the intact coating, $\mathrm{R}_{\mathrm{po}}$ - pore resistance, $\mathrm{R}_{\mathrm{ct}}$ - charge transfer resistance, $R_{s}$ - solution resistance, $C_{d l}$ - double layer capacitance

\section{Scheme 1}


When mild steel was immersed in SCPS prepared in rainwater the two semi circles disappear and one semicircle appears. This is characteristic of diffusion controlled process ${ }^{42}$. When mild steel was immersed in rainwater two semicircles were obtained one was due to polarization resistance and other was due to pores resistance. From this it is clear that when mild steel was immersed in rainwater a porous inhibitive film was formed. When concrete pore solution was added to rainwater, the two semicircles were disappeared. Only one semicircle with polarization resistance was noticed. This indicates that addition of concrete pore solution to rainwater reduces the porosity of the inhibitor film. The curve obtained is of diffusing control type. This indicates that when concrete pore solution was added, the inhibitor (Saturated calcium hydroxide) diffusion continuously in the pores of the film and on the damaged part of the inhibitor film. Similar observation has been made by Gunasekaran et al. ${ }^{42}$, while studying inhibition of corrosion of carbon steel by tartarate ion. Leemarose et al. noticed similar observation while studying corrosion inhibition of carbon steel by sodium dodecyl sulphate ${ }^{43}$

The various ions present in simulated concrete pore solution diffuse towards the metal surface and form a stable protective film formed on the metal surface. Equivalent circuit diagram for such a system is shown in Scheme 2. The circuit models a cell where polarization is due to a combination of kinetic and diffusion process.

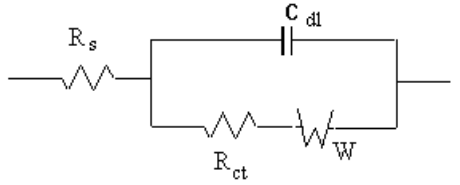

$\mathrm{R}_{\mathrm{s}}$ - Solution resistance, $\mathrm{R}_{\mathrm{ct}}$ - Charge transfer resistance, $\mathrm{W}$ - Warburg diffusion resistance, $\mathrm{C}_{\mathrm{dl}}$ - Double layer capacitance

\section{Scheme 2}

When mild steel was immersed in well water, the $R_{t}$ value was 825 ohmcm $^{2}$. When it was immersed in simulated concrete pore solution prepared in well water, the $\mathrm{R}_{\mathrm{t}}$ value tremendously increases from 825 to $38460 \mathrm{ohmcm} \mathrm{mc}^{2}$. This indicates that a stable protective film is formed on the metal surface in presence of SCPS. This is further supported by the decrease in $\mathrm{C}_{\mathrm{dl}}$ value from $6.18 \times 10^{-5}$ to $1.326 \times 10^{-5}$. The impedance value increases from 3.37 to 4.6 (Figures 8 and 9).

When mild steel was immersed in well water two semi circles were observed. This is characteristic of a corroding system. The equivalent circuit is shown Scheme 1. When mild steel was immersed in SCPS prepared in well water, the Nyquist plot observed is characteristic of a diffusion controlled process (Figures 5 and 6). The enlarged figure of 5 is shown in Figure 6. It reveals that the corrosion process is a diffusion controlled process The ions present in well water and SCPS diffused towards the metal surface and formed a protective film which is stable.

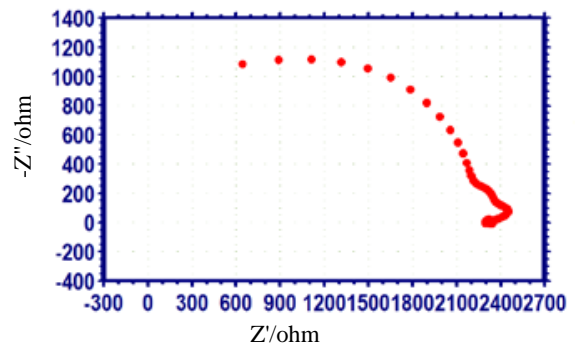

Figure 4. AC Impedance spectrum of mild steel immersed in well water (Nyquist plot)

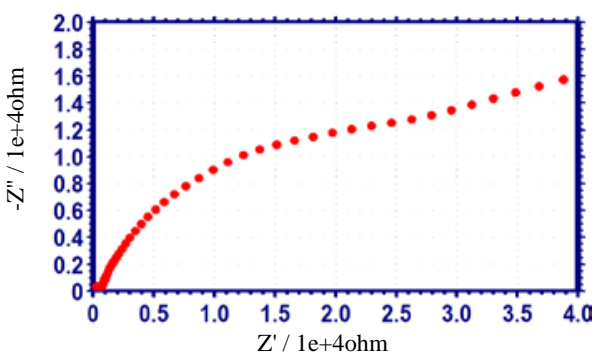

Figure 5. AC Impedance spectrum of mild steel immersed in SCPS prepared in well water (Nyquist plot) 


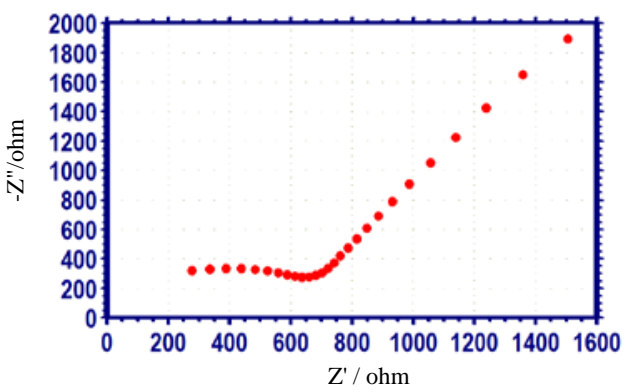

Figure 6. Enlarged Figure of Figure 5

The equivalent circuit is shown in Scheme 2. It is observed from Bode plots (Figures 7 and 8) that when mild steel was immersed in well water, the phase angle is 52 degree. In presence of SCPS the phase angle increases from 52 to 54 degree. A single time constant is observed (Figure 8).
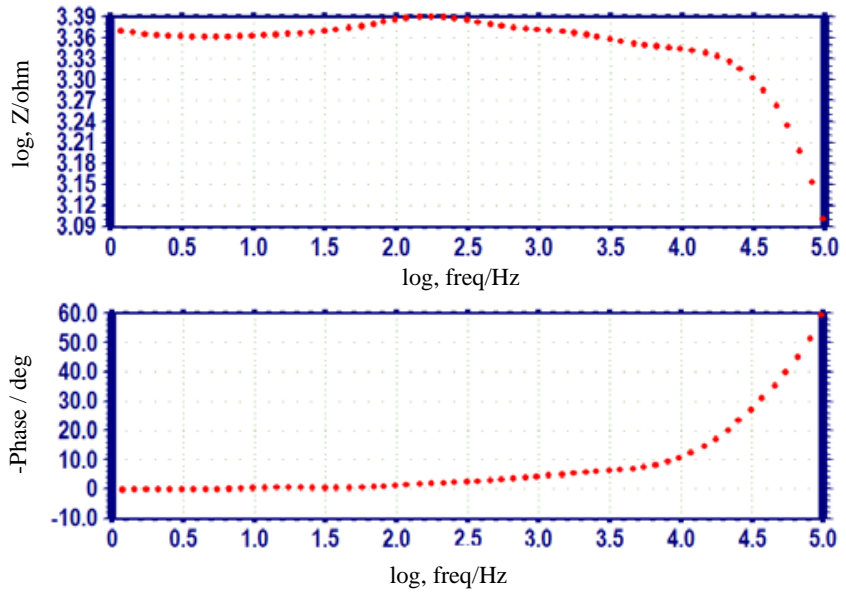

Figure 7. AC impedance spectrum of mild steel immersed in well water (Bode plot)
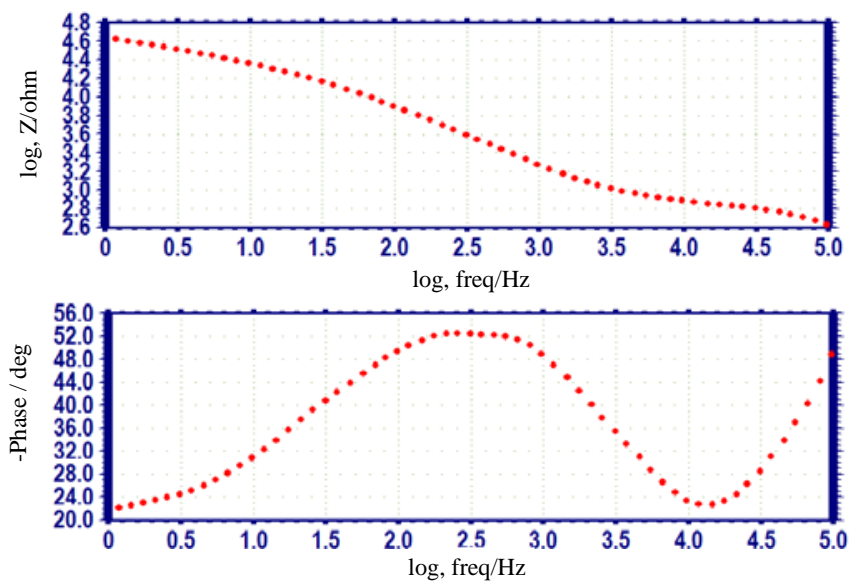

Figure 8. AC impedance spectrum of mild steel immersed in SCPS prepared in well water (Bode plot) 
When mild steel was immersed in seawater, the $\mathrm{R}_{\mathrm{t}}$ value is $83.06 \mathrm{ohmcm}^{2}$. When SCPS was added the $R_{t}$ value decreases from 83.06 to $80.48 \mathrm{ohmcm}^{2}$. This indicates that the protective film formed is not stable and the metal undergoes corrosion. This supported by the fact that $\mathrm{C}_{\mathrm{dl}}$ value increases from $6.14 \times 10^{-4}$ to $6.33 \times 10^{-4} \mathrm{~F} / \mathrm{cm}^{2}$, further the impedance value decreases from 2.10 to2.09 (Figures 10 and 11). In presence of SCPS, the phase angle value decreases from 54 to 50 degree which is characteristic of a corroding system. The equivalent circuit diagram for the corroding system (Figure 9) is shown in Scheme 3.

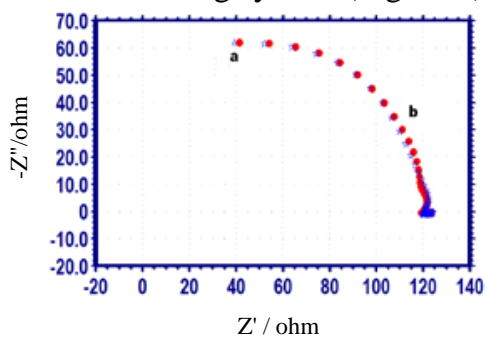

Figure 9. AC Impedance spectra of mild steel immersed in various test solutions (Nyquist plot); a) Seawater. b) SCPS prepared in seawater
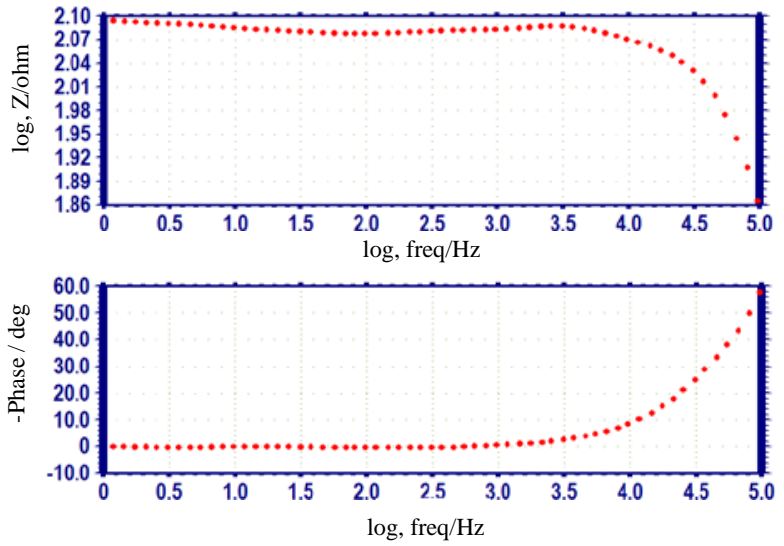

Figure 10. AC impedance spectrum of mild steel immersed in seawater (Bode plot)
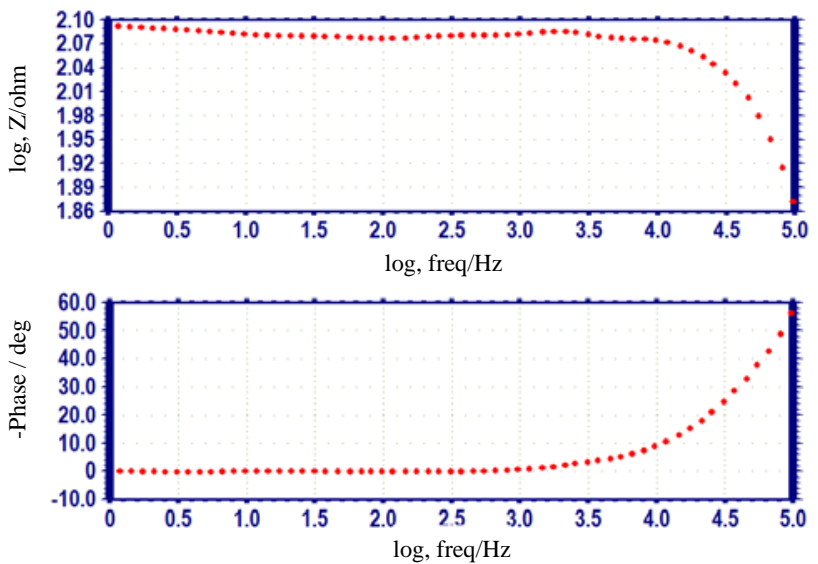

Figure 11. AC Impedance spectrum of mild steel immersed in SCPS prepared in seawater (Bode plot) 


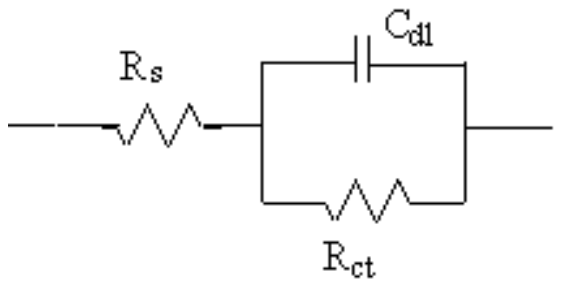

$\mathrm{C}_{\mathrm{dl}}$ - Double layer capacitance. $\mathrm{R}_{\mathrm{s}}$ - Solution resistance, $\mathrm{R}_{\mathrm{ct}}$ - Charge transfer resistance

\section{Scheme 3}

It is observed from the study that the corrosion resistance of mild steel immersed in SCPS prepared in various water samples namely rainwater, well water and seawater is in the following order: Rainwater>well water>seawater.

\section{Conclusion}

The corrosion resistance of mild steel immersed in simulate concrete pore solution (SCPS) prepared in various water samples namely rainwater, well water and seawater has been evaluated by electrochemical impedance spectra. The corrosion resistance of mild steel is in the following order: Rainwater>well water>seawater. It is recommended to prepare concrete admixtures in rainwater rather than well water (or) seawater.

\section{References}

1. Ahmad S, Cement Concrete Comp., 2003, 25, 459.

2. Biezma M V and San J R, Cristobal, Corros Eng Sci Technol., 2005, 40, 344.

3. Thangavel K, Corros Rev., 2004, 22, 55.

4. Moreno M, Morris W, Alvarez M.G and Duffo G S, Corros Sci., 2004, 46(11), 2681-2699.

5. Kumar V, Corros Rev., 1998, 16, 317.

6. Maslehuddin M, Al-Zahrani M M, Ibrahim M, Al-Mehthel M H and Al-Idi S H, Constr Build Mater., 2007, 21(8), 1825-1832.

7. $\quad$ Du R.G, Hu R.G, Huang R.S and Lin C J, Anal Chem., 2006, 78(9), 3179-3185.

8. Huet B, L'Hostis V, Miserque F and Idrissi H, Electrochem Acta, 2005, 51(1), 172-180.

9. Alonso C, Castellote M and Andrade C, Electrochim Acta, 2002, 47(21), 3469-3481.

10. Poupard O, Ait-Mokhtar A and Dumargue P, Cement Concrete Res., 2004, 34, 991-1000.

11. Duffo G S, Morris W, Raspini I and Saragovi C, Corros Sci., 2004, 46, 2143.

12. Yeih W C and Chang J, J Constr Build Mater., 2005, 19, 516.

13. Garces P, Andrade M C, Saez A and Alonso M C, Corros Sci., 2005, 47(2), 289-306.

14. Zhou X, Yang H Y and Wang F H, Corros Sci Protect Technol., 2010, 22(4), 343-347.

15. Fajardo S, Bastidas D M, Ryan M P, Criado M, McPhail D S and Bastidas J M, Appl Surface Sci., 2010, 256(21), 6139-6143.

16. Chen W, Du R G, Ye C-Q, Zhu Y-F and Lin C-J, Electrochim Acta, 2010, 55(20), 5677- 5682.

17. Wang L and Zhao Y-L, Tiedao Xuebao/J China Railway Soc., 2010, 32(4), 96-101.

18. Chastre C and Silva M A G, Eng Struct., 2010, 32(8), 2268-2277.

19. Suh K, Mullins G, Sen R and Winters D, J Compos Constr., 2010, 14(4), 388-396.

20. Zhang J X, Sun H H, Sun Y M and Zhang N, J Zhejiang University Sci A, 2010, 11(5), 382-388.

21. Dao V T N, Dux P F, Morris P H and Carse A H, ACI Mater J., 2010, 107(3), 291-296.

22. Ghods P, Isgor O B, McRae G A and Gu G P, Corrosion Sci., 2010, 52(5), 1649-1659. 
23. Fan Y F, Hu Z Q, Zhang Y Z and Liu J L, Construct Build Mater., 2010, 24(10), 1975-1983.

24. Pandiarajan M, Prabhakar P and Rajendran S, Eur Chem Bull., 2012, 1(7), 238-240.

25. Huet B, L'Hostis V, Tricheux L and Idrissi H, Mater Corros., 2010, 61(2), 111-124.

26. Allahkaram S R and Khodayari M, Anti-Corros Methods Mater., 2008, 55, 250.

27. Mennucci M M, Banczek E P, Rodrigues P R P and Costa I, Cement Concrete Compost., 2009, 31, 418.

28. Kitowski C J and Wheat H G, Corrosion, 1997, 53, 216.

29. Hurley M F and Scully J R, Corrosion, 2006, 62(10), 892-904.

30. Li L and Sagues A.A, Corrosion, 2004, 60, 195.

31. Arockia Selvi J, Rajendran S, Garga Sri V, John Amalraj A and Narayanasamy B Portugaliae Electrochim Acta, 2009, 27( 1), 1-11.

32. Shyamaladevi B and Rajendran S, Eur Chem Bull., 2012, 1(2), 503-510.

33. Kalaivani R, Narayanaswamy B, Selvi J A, Amalraj A J, Jeyasundari J and Rajendran S, Portugaliae Electrochemica Acta, 2009, 27(2), 177-187

34. Anthony Samy Sahayaraja and Susai Rajendran, J Electrochem Sci Eng., 2012, 2, 91-104

35. Manimaran N, Rajendran S, Manivannan M and Johnmary S, Res J Chem Sci., 2012, 2(3), 52-57.

36. Sribharathy V and Susai Rajendran S, Res J Chem Sci., 2012, 2(6),72-81.

37. Mary Anbarasi C, Susai Rajendran, Vijaya N, Manivannan M and Shanthi T, Open Corros J., 2011, 4, 40-46.

38. Johnsirani V, Rajendran S, Sathiyabama J, Muthumegala T S, Krishnaveni A and Hajarabeevi N, Bulgarian Chem Commun., 2012, 44(1), 41-51.

39. Sangeetha M, Rajendran S, Sathiyabama J, Krishnaveni A, Shanthy P, Manimaran N and Shyamaladevi B, Portugaliae Electrochimica Acta, 2011, 29(6), 429-444.

40. Rajendran S, Uma V, Krishnaveni A, Jeyasundari J, Shyamaladevi B and Manivannan M, Arabian J Sci Eng., 2009, 34(2C), 149-158.

41. Noreen Antony, Benita Sherine H and Susai Rajendran, Portugaliae Electrochimica Acta, 2010, 28(1), 1-14.

42. Gunasekaran G, Natarajan R and Palaniswamy N, Corros Sci., 2001, 43, 1615-1626.

43. Leemarose A. Peter Pasgal Regis A, Susai Rajendran, Krishnaveni A and Felicia Rajammal Selvarani, Arabian J Sci Eng., 2012, 37(5), 1313-1325. 